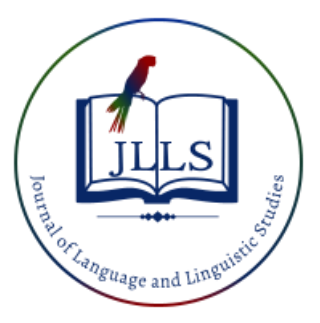

Available online at www.jlls.org

JOURNAL OF LANGUAGE AND LINGUISTIC STUDIES

ISSN: 1305-578X

Journal of Language and Linguistic Studies, 17(2), 958-970; 2021

\title{
Technology in teaching speaking and its effects to students learning English
}

\author{
Rowena V. Sosas a 1 iD \\ APA Citation: \\ ${ }^{a}$ University of Southern Mindanao, Philippines
}

Sosas, R.V. (2021). Technology in teaching speaking and its effects to students learning English. Journal of Language and Linguistic Studies, 17(2), 958-970. Doi: 10.52462/j1ls.66

Submission Date:02/02/2021

Acceptance Date:30/04/2021

\begin{abstract}
This paper presents the technology used in teaching speaking and its effects to students as they learn to speak in English. Phenomenology was used to gather the data with the three groups of Focus Group Discussion (FGD) of 21 participants from the junior, sophomore and senior students in language classes in the University of Southern Mindanao, Kidapawan City Campus, and Philippines. Results revealed that students are taught to speak in English using the technologies of today such as video conferencing, email correspondence, social media interaction and real-time actual emceeing and onstage speaking performances where students are engaged in real academic and professional situations. Moreover, findings revealed that these technologies in teaching speaking build rapport, increase fluency and accuracy, ease anxiety and apprehension, and build confidence among students. Apparently, the researcher found that the technology used in teaching speaking can be aligned with the communicative way of teaching which allows students to convey themselves in a skillful and competent way of communication.
\end{abstract}

Keywords: phenomenology; effects; technology; teaching speaking; focus group discussion

\section{Introduction}

Speaking is one of the macro skills in English that instructors and students must polish. A good speech is accompanied by fluency and accuracy which students must learn and enhance competitively. Teaching speaking has been given much importance at school for many years. It has been part of every curriculum but it is undervalued that teaching speaking is only through memorization and repetition of drills focusing on the fluency of the production of sounds (Kayi, 2012). However, in these recent times that the English language is dubbed to be the second most popular language with approximately 400 million native speakers (Top Ten Languages, 2016) that makes the English language the lingua franca of the world, teaching speaking requires innovative ways and methods rather than teaching speaking through memorization and parroting.

For a country like the Philippines with 117 different dialects, where most students do not get to use English in their daily conversations, and where most times students do not get to talk with Englishspeaking people, it is with great concern on how instructors teach their students to speak in English

\footnotetext{
1 Corresponding author.

E-mail address: rvsosas@usm.edu.ph
} 
and master their skill using it. Hence, this research study explored how students are taught to speak in English and how these methodologies have enhanced their speaking competence.

\subsection{Literature Review}

There is a mushrooming body of research about how speaking is taught to students especially using the English language. This is because of the knowledge that teachers resourceful as they are resorting to different strategies, techniques and approaches in developing and shaping the speaking skill of students. They use various ways and implement different methodologies in developing student's communicative competence. They design courses to help students find English learning more enjoyable for them to develop a better attitude (Noom-ura, 2008).

Various researches have been conducted to find out which approaches and strategies are the best and more effective in developing communicative competence. Koşar (2019) determined the significant difference in speaking performances of students being taught by native and non-native English speakers. Some even recommended knowledge and practice in developing speaking skills after a research study. Murad and Smadi (2009) recommended that teachers may adopt task-based language teaching principles and procedures in their classroom practices within and pre-service training programs to develop teachers' ability to use task-based language teaching when designing and executing lesson plans. Yüzlü and Derin (2020) examined the impact of the use of L1 on the EFL learners' L2 speaking skills as well as their perceptions of L1 use in fostering oral production in L2.

Some conducted research on effectivity of a strategy used in developing communicative competence. Qing (2011) stated that role play is a very valuable method to help learners to interact and provide them an opportunity to practice in the target language context. It further suggested the application of role plays to increase student's intercultural awareness and to help them develop overall communicative competence. More so, Aliakbari and Jamalvandi (2010) stated that role play is a praised technique in task-based language teaching which has a positive effect on students' speaking skills.

Besides, utilizing technology in teaching methods is a fundamental practice in teaching EFL, where it is available and accessible. Suggestions to incorporate the use of technology in teaching speaking have been stated. The use of CMC (computer-mediated communication) in teaching pronunciation and conversation is put forward to improve students' oral skills (Hong, 2006).

With the technology used in teaching language skills, McDougald (2009) also revealed that ICT is definitely a complement to conventional teaching, especially when developing reading, writing and listening skills in English. The use of technology in teaching speaking is one of the changes in how languages are taught in school which focuses on the use of language communication rather than just passing the examination (Thao, 2003).

Besides, Bahadorfar and Omidvar (2014) also stated that technological tools like the internet, podcasts, video conferencing, videos, and speech recognition software are considered the best tools for teaching speaking skills and using such tools have been regarded as ways of helping students improve language skills. Moreover, Huang and Hung (2010) also state that an e-portfolio is a technology that allows students to have lexical richness in speaking in which learners benefit from their oral performances. Using such technology in teaching speaking is immensely acceptable by students.

Similarly, the internet, podcasts, video conferencing, videos and speech recognition software, TELL, blogging is considered to be some of the best tools for teaching speaking skills (Parveen, 2016). Using these technologies has become the mode of communication of instructors and students for the present day which implies that technology is needed to get into the modernized world. 
Technology has become an additional tool for teaching in enhancing their students' speaking competence.

The utilization of technology in teaching speaking has become an essential practice particularly in teaching English as a foreign language (Hong, 2006). It stated that computer-mediated communication in teaching pronunciation and conversation is initially focused to improve students' oral performance. Speech laboratory is also of great importance in teaching speaking and speech articulation along with many technological tools of today (Margret, 2010).

In addition, video applications for conferencing are also considered an essential computer-mediated communication tool in promoting speaking fluency and accuracy. It caters to social interaction purposes and it serves as oral reinforcement of both language fluency, accuracy and course contents outside of classroom settings (Romaña Correa, 2015).

In like manner, digital storytelling is one powerful technology tool for teaching speaking. It integrates computer technologies and the art of storytelling in which graphic designs such as texts, images, and audio are combined making it into a creative media of storytelling. More so, digital storytelling in the classroom has enhanced and developed students in English speaking skills for it allows students to story-tell using their own words and voice (Somdee and Suppasetseree, 2013). Cartoons on television and other digital platforms also enhance students' speaking skill. Cartoons provide audio and visuals, to attract attention, therefore, develop students' motivation towards the learning of speaking (Fata \& Wahyuni, 2016).

Also, using Information Communication Technology (ICT) enhances speaking skill, motivation and oral performances (Idayani \& Sailun, 2017). It has a huge and significant impact on students learning effectiveness in which students claim to have their speaking ability, knowledge and creativity enhanced. The use of multimedia as learning material as one of the ICT technologies was recorded as significantly effective in honing student's ability to speak in English (Ampa, Rasyid, and Rahman, 2013). Video blogging is effective as it promotes students' learning motivation (Rakhmanina and Kusumaningrum, 2017). In like manner, Smartphone overcomes speaking anxiety Machmud and Abdulah (2017) that groups of students with high and low anxiety obtained higher score when they are taught using Smartphone compared to their score when they are taught using a conventional model of teaching of speaking. Further, Akkara, Anumula and Mallampalli (2020) described that there is a significant difference in the speaking ability of students when taught speaking using technology such as WhatsApp interaction. Using technology in teaching speaking with the experimental group has a larger significance in English fluency compared to the other group taught to speak in English using the traditional method. In addition, Rodrigues and Vethamani (2015) find out that there is greater language proficiency and stronger self-confidence amongst learners of English as a second language as they develop their speaking skills.

Using technology in teaching speaking brings a number of positive results on the part of the learners. Goh (2016) stated that technology in teaching speaking develops language fluency, accuracy and complexity. As well, Akkara, Anumula and Mallampalli (2020) stated that using technology in teaching speaking improves students' speaking fluency and coherence, lexical resource, grammatical range and accuracy and pronunciation. More so, technology in teaching speaking improves students' speaking skills and employing such has a positive impact on learners speaking skills, fluency, and pronunciation. It also overcomes students' speaking difficulty (Hamad, Metwally \& Alfaruque, 2019). 


\subsection{Research questions}

The study investigates how students are taught to speak in English by their instructors. Specifically, it aimed to answer the following questions:

1. How students are taught to speak in English?

2. How it helped enhance speaking competence?

\section{Method}

\subsection{Sample / Participants}

There were three sets of participants involved in this study. Each set is composed of seven students from sophomore, junior and senior language classes of the Bachelor of Secondary Education program of the University of Southern Mindanao Kidapawan City Campus, Philippines. Stratified random sampling was conducted to identify the participants from each language class section. Each of the students' names was written on a small piece of paper and was picked and chosen as participants. This gives all students an equal chance to be the participants of the study thus avoiding biases in the selection process. From each section, seven names were picked. From the three sections of the language class, three sets of Focus Group Discussion (FGD) participants were formed with seven participants per set with a total of 21 students. These participants have already enrolled and passed the speaking courses. They were taught by different instructors of the same level in terms of educational attainment and status of permanency. Participants were chosen regardless of sex and gender. They were of the same age ranging from 17-19 years old. They are all majoring in English in their BSE program.

\subsection{Instrument / Material}

To extract data, this research study used a question guide formulated from the research questions. There were two research questions with at least five probing questions each with which were subjected to experts' evaluation and validation. The question guide was used to interview the participants during the focus group discussion from which the data were extracted.

\subsection{Data Collection and Analysis}

This study was first proposed and presented to the University research department for suggestions and approval. After which was the permission of the campus university chancellor for the conduct of the study.

Secondly, after the approval was given, the researcher met the three sections of the language class. Students were explained the research content, problem, procedure, outcome and everything about the research project. The researcher built rapport towards the students at this phase to develop friendship and ease which helped extract genuine answers from the questions during the conduct of the FGD. Then, the researcher asked permission of the students to become the participants of the study.

Thirdly, a random sampling procedure in selecting the participants was conducted and lastly, after the orientation and explanation of the research content, the focus group discussions were conducted. The data were extracted and gathered using the recorder and were saved for audit trail purposes.

Moreover, the researcher visited the participants in their natural setting in the classroom to have authentic and common feelings not to ignite nervousness and excitement. This was best do to capture 
the natural environment of the participants to gather authentic data aside from building rapport. The recorded answers from the FGD were then transcribed for the thematic analysis.

After the transcription of the recorded answers, the same was given back to the participants for selfverification and review of their answers and responses during the FGD (Morrow Rodriguez \& King, 2015). Then, the verified transcription was thematically analyzed and interpreted into themes and core ideas (Miles and Huberman, 1994). The data were again given back to the participants for confirmation and verification adhering to Collaizi's method of verification (Morrow Rodriguez \& King, 2015). The thematic analysis includes data transcription, recording of patterns and common themes, recording of interesting stories that emerged and analysis of the frequency of response. The analysis of the data includes data reduction, display and conclusion drawing Miles and Huberman (1994) and lastly was Collaizi's method of verification.

\section{Results and Discussion}

Table 1. The technology used in teaching speaking

\begin{tabular}{|l|l|l|}
\hline \multicolumn{1}{|c|}{ Themes } & $\begin{array}{c}\text { Frequency of } \\
\text { response }\end{array}$ & \multicolumn{1}{c|}{ Core ideas } \\
\hline video conferencing & general & $\begin{array}{l}\text { "She talks to us on videos using skype. " } \\
\text { (FGD2CS2) }\end{array}$ \\
\hline email correspondence & general & $\begin{array}{l}\text { "First, she asked us to have an official and } \\
\text { professional email account. She tells [told] us to } \\
\text { have one. }{ }_{F G D I S 7}\end{array}$ \\
\hline $\begin{array}{l}\text { hocial media conversation } \\
\text { speaking and on-stage } \\
\text { performances }\end{array}$ & $\begin{array}{l}\text { She employed authentic tasks like using social } \\
\text { media for conversation..." FGD2S1 }\end{array}$ \\
\hline
\end{tabular}

Legend:

General $50 \%$ up

Typical $25 \%-40 \%$

Variant $20 \%$ down

Table 1 shows the technology used by instructors in teaching speaking. The three groups of Focus Group Discussion (FGD) detailed that students were taught by language instructors to speak in English with the use of technology in carrying out communicative tasks. It was found that instructors made use of the available technology in employing task-based activities. Generally, instructors did video conferencing, email correspondence and social media conversation. Emceeing and on-stage speaking performances on the other hand are done typically.

Video conferencing was done as participants detailed. They said:

$$
\begin{aligned}
& \text { "We talk[ed] in the group at night using Skype video } \\
& \text { especially during our home reading activity." FGDIS3 } \\
& \text { "When our instructor miss[ed] the class, she conducted } \\
& \text { makeup classes through video conference on messenger } \\
& \text { and she starts[ed] to lecture and instructs. . " "FGD2S4 }
\end{aligned}
$$

Video conferencing on Skype and messenger as what the participants stated above was done by the instructor to cope with the missed classes and as a supplemental activity to give way for the lecture 
and instruction. This implies that the instructor is making use of the available technology resources to cope with classes and to reach out to students in any way possible. It also explains that technology has become an avenue for the instructor to be with students in doing their home reading activities.

Other than video conferencing, Email correspondence was also employed by instructors in teaching speaking where students are tasked to write properly constructed statements as they correspond. Participants said:

"She let us download instructional materials through
attachments in our email accounts. She could have done
using USB sticks yet she chose to send them over the
internet into our email accounts. We actually were
exchanging formal statements in there." FGD2S3
"First, she asked us to have an official and professional
email account. She tells [told] us to have one." FGD3S5
"Instructions were sent to our email accounts. She sent
instructional worksheets also. We are tasked to
communicate and ask questions in our email rather than
texting." FGD3S7

Email correspondence as what is detailed by the participants was also employed. Using this technology, students get to talk formal language with their instructor in which email correspondence is preferred rather than mobile texting where students are prone to using the informal exchange of talk. This explains that students are obliged to use formal sentence structures in exchanging messages with their instructor. Using their official email accounts, students have the feel of talking in serious and professional as they deal with communication through email correspondence.

Further, social media conversation was also employed by the instructor as what participants revealed. They stated:

\section{"Our instructor replies to our comments on Facebook using the English language." ${ }_{F G D 3 S 2}$ \\ "She was actually talking to us in the comment section of the post and on private message. . ." FGDIS6 \\ "Usually she posted intriguing posts on Facebook that as I understood she just wanted to ignite ideas and to encourage online conversation. ${ }_{F G D I S 4}$}

With conversation on social media amongst students and instructor, the instructor replied to comments, answered private messages and talked to students in public posts. This implies that the instructor is making use of the technology to cater the communication online. This explains that they make themselves available for online communication with their students to encourage them to converse.

Further, in a typical manner, emceeing and onstage speaking performances were also employed by instructors in teaching students to speak in English. One participant revealed that she was tasked twice to emcee a university event. She said: 
"During our first meeting, our instructor already told us that she will be recommending us to emcee an event in the University and I was tasked twice to do it. " ${ }_{F G D 2 S 4}$

"I am[was] given a task to moderate a forum on drug addiction in our college." FGD2SI

"During the [Filipino] festival [Buwan ng Wika], Annilou is[was] tasked to read the introduction of the guest of honor and speaker." ${ }_{F G D 2 S 3}$

"We were made to run the program. We had been tasked with communication and information dissemination through announcements in the nerve center. ${ }_{F G D I S S}$

"We were [were] the ones giving announcements before an event ends." ${ }_{F G D 3 S 5}$

"In the programs and events in the University, we are asked to handle the tasks especially emceeing and hosting and even moderating a forum all throughout the semester." FGDISS

Tasking students to host and Emcee University events was also done by the instructors. As what participants revealed that their instructor arranged beforehand their emceeing events, it implies that instructors are serious enough in improving students' speaking competence. This is not only enhancing their skill but also addressing speaking difficulty in a crowd and as well their speaking anxiety.

The findings of this study in which it is revealed that instructors used technology in teaching speaking rather than the traditional method of teaching run parallel with Thao (2003) which states that there have been changes for years on how languages are taught in school. The focus is no longer on the examination to pass but to use the language for communication.

As well, Bahadorfar and Omidvar (2014) state that technological tools have been regarded as ways of helping students improve language skills such as speaking skills. Internet, podcasts, video conferencing, videos and speech recognition software are considered the best tools for teaching speaking skills.

Huang and Hung (2010) also state that technology such as e-portfolio allows students to have lexical richness in speaking in which learners benefit from their oral performances. It was found that using digital portfolios in teaching speaking is immensely acceptable by the students.

Likewise, Parveen (2016) mentioned that the Internet, podcasts, video conferencing, videos and speech recognition software, TELL, blogging is considered to be some of the best tools for teaching speaking skills. It states that technology is used in teaching speaking rather than in trades and business transactions. It has become the mode of communication of instructors and students for the present day are driven by technology which implies that technology is needed to get into the modernized world. Technology has become an additional tool for teaching in enhancing their students' speaking competence.

Further, Hong (2006) stated that the utilization of technology in teaching speaking has become an essential practice particularly in teaching English as a foreign language. Computer-mediated 
communication in teaching pronunciation and conversation is initially focused to improve students' oral performance. Speech laboratory is also of great importance in teaching speaking and speech articulation along with many technological tools of today (Margret, 2010).

In addition, Romaña Correa (2015) explained that video applications for conferencing are also considered an essential computer-mediated communication tool in promoting speaking fluency and accuracy. It caters to social interaction purposes and it serves as oral reinforcement of language fluency, accuracy and course contents outside of classroom settings.

In like manner, Somdee and Suppasetseree (2013) also explained that one powerful technology tool for teaching speaking in education is digital storytelling in which integrates computer technologies and the art of storytelling. It combines all graphic designs such as texts, images, and audio making it into a creative media of storytelling. More so, digital storytelling in the classroom has enhanced and developed students in their English speaking skills for it allows students to story-tell using their own words and voice.

Besides, Fata and Wahyuni (2016) stated that watching cartoons on television and other digital platforms enhances students' speaking skills. Cartoons provide audio and visuals to attract attention, therefore, develop students' motivation towards the learning of speaking.

Idayani and Sailun (2017) as well stated that Information Communication Technology (ICT) is used to enhance students' English proficiency, especially speaking skills. The use of ICT enhances students' motivation and their oral performances. It has a huge and significant impact on students learning effectiveness. A number of students stated that their instructor incorporates technology in teaching them how to speak in English. Students even claimed that using ICT has been beneficial and helpful for them to use the language. Most of them confirmed that the use of technology in teaching speaking by their instructor has enhanced their speaking ability, increased their knowledge, and creativity.

Likewise, Machmud and Abdulah (2017) stated that technology like smartphones is used in teaching speaking in which anxiety in speaking English is overcome. It revealed that groups of students with high and low anxiety obtained higher scores when they are taught using smartphones compared to their score when they are taught using the conventional model of teaching. As well, Ampa, Rasyid, and Rahman (2013) stated that using multimedia learning materials in teaching speaking was significantly effective in honing student's ability to speak in English.

Table 2. Effects of using technology in teaching speaking

\begin{tabular}{|c|c|c|}
\hline Themes & $\begin{array}{l}\text { Frequency of } \\
\text { response }\end{array}$ & Core ideas \\
\hline builds rapport & general & $\begin{array}{l}\text { "Online and casual communication builds friendship } \\
\text { between me and my instructor." }\end{array}$ \\
\hline $\begin{array}{l}\text { increases fluency and } \\
\text { accuracy }\end{array}$ & general & $\begin{array}{l}\text { "We learn how to speak properly with clear } \\
\text { intonation pattern and proper phrasing of the } \\
\text { sentence because we practice it before the actual } \\
\text { task." FGD3S4 }\end{array}$ \\
\hline $\begin{array}{l}\text { eases anxiety and } \\
\text { consciousness }\end{array}$ & general & $\begin{array}{l}\text { "I was able to overcome my speaking anxiety (and } \\
\text { even I am nervous at first) but with the activity, with } \\
\text { ma'am talking to us like she's like (only) a student, it } \\
\text { eased me up and made me comfortable in speaking." } \\
\text { FGD3S7 }\end{array}$ \\
\hline builds confidence & typical & $\begin{array}{l}\text { "It boosts our confidence and fluency because the activity } \\
\text { we had built rapport between us and our instructor." } \\
\text { FGD2S5 }\end{array}$ \\
\hline
\end{tabular}


Legend:

General $50 \%$ up

Typical $25 \%-40 \%$

Variant $20 \%$ down

Table 2 shows the effects of using technology in teaching speaking. Using technological tools in carrying out the tasks for speaking builds rapport, increases fluency and accuracy, eases anxiety and consciousness in general and it typically builds confidence as well amongst students. They said:

"Using the social media, deletes my being conscious

talking to my instructor and classmates. " FGDIS4

"Online and casual communication builds friendship

between me and my instructor. ${ }_{F G D 3 S 7}$

"It allows me to talk without being nervous." ${ }_{F G D 3 S 6}$

Participants as what they detailed above said that the use of technology in teaching speaking builds rapport between them and their instructor. This implies that friendship is developed which eventually allowed them to feel that they belong to the group. They feel comfortable with the friendship being developed.

More so, the use of technology in teaching speaking increases the fluency and accuracy of students in speaking. They said that:

"We learn how to speak properly with clear intonation pattern and proper phrasing of the sentence because we practice it before the actual task." FGD3S4

"It gives us time to think first what we are to utter so we minimize errors and mistakes." ${ }_{F G D I S 6}$

"Casual communication eased us in talking. We are not intimidated." FGDIS6

“...I am able to correct my own speech difficulty. ${ }_{F G D 3 S 7}$

With the use of technology in teaching speaking, students are able to increase their speaking fluency and accuracy as they communicate. This is so for they can address their speech difficulty, they learn to speak properly and they think before they engage in actual conversation online. This implies that students are given favorable time to repair their own speech faults may it be in pronunciation, words or phrases thus increases their speech fluency and accuracy.

Further, the technology used in teaching speaking eases the anxiety and apprehension of students. They said:

\footnotetext{
"I was able to overcome my speaking anxiety (and even I am nervous at first) but with the activity, with ma'am talking to us like she's like (only) a student, it eased me up and made me comfortable in speaking. " ${ }_{F G D 3 S 7}$
}

"With the activities, we had (with oral reading as our final exam, we were not that very conscious anymore and we feel not anxious) because we already had series 


\section{of activities that really had taken our guilt (in) speech. It has really taken our nervousness and the being conscious.)" ${ }_{F G D 3 S 5}$}

In speaking, anxiety and apprehension are already built-in. In like manner with the students learning to speak in English, it is but expected that students may be anxious when performing oral performances and communication. They have fears and doubts in them especially when they will be talking using a second or foreign language like English. But with the technology, the instructor used in teaching speaking, eases the students' anxiety and apprehensions. This implies that students perform well in speaking and communication when there is a channel of communication like technology for it does not require face-to-face interaction in which students do not see the instructor's facial expression, preferences and manner that can add up to their fears and apprehensions.

Besides, the use of technology in teaching speaking builds confidence as what participants typically have shared. They said:

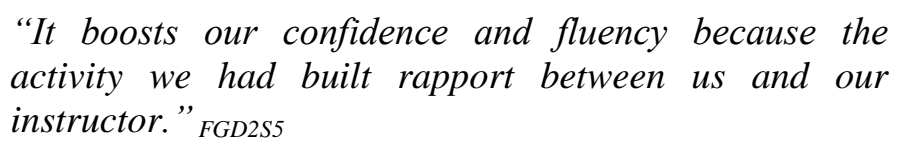

"With the activity we had, it builds my confidence. I am able to speak now and overcome my stage freight because we practice a lot before the actual task." ${ }_{F G D 3 S 6}$

Technology in teaching speaking as what participants detailed above builds confidence. It allows students to boost and build their confidence. It has become a way that students overcome their speaking difficulty in a crowd for technology allows them to practice before the speaking engagement.

Using technology in teaching speaking brings a number of positive results on the part of the learners. The findings of this study are in a like manner with that of numerous studies on teaching speaking with the use of technologies of today's modern world. The findings run parallel with Rakhmanina and Kusumaningrum (2017) which states that learning speaking through technology like video blogging is effective as it promotes students' learning motivation.

As well, findings are in conformance with Machmud and Abdulah (2017) which states that using technology like smartphones in teaching speaking overcomes anxiety in speaking English. It revealed that groups of students with high and low anxiety obtained higher scores when taught using technology like smartphones compared to those who are not.

Goh (2016) also stated that technology in teaching speaking develops language fluency, accuracy and complexity. In addition, Rodrigues and Vethamani (2015) find out that there is greater language proficiency and stronger self-confidence amongst learners of English as a second language as they develop their speaking skills.

Further, Akkara, Anumula and Mallampalli (2020) described that there is a significant difference in the speaking ability of students when taught speaking using technology such as WhatsApp interaction. It stated that using technology in teaching speaking improves students' speaking fluency and coherence, lexical resource, grammatical range and accuracy and pronunciation. It further explained that there is a change in the perception of students in terms of their speaking skills.

Using technology in teaching speaking with the experimental group has a larger significance in English fluency compared to the other group taught to speak in English using the traditional method; 
however, in terms of progress in accuracy and pronunciation, the two groups being studied were similar (Sun, Lin, You, Shen, Qi, \& Luo, 2017).

More so, technology in teaching speaking like YouTube videos and Listening Audio Tracks Imitation (YATI) is a very effective Computer-Assisted Language Learning tool towards improving students' speaking skills. Employing such in the teaching and learning process has a positive impact on learners in terms of their speaking skills, fluency and pronunciation. Using technology in teaching speaking is greatly recommended to help learners overcome their speaking difficulties (Hamad, Metwally \& Alfaruque, 2019).

\section{Conclusion}

The results of the study revealed that the technologies of today have become an effective platform in teaching speaking. It is an additional input of instructors apart from lecturing. Instructors do not employ traditional approaches nor use outmoded modes of teaching speaking like chalk and board lecture in tasking the students to learn to speak, instead, they make use of the technologies of today as their medium.

After laying down the results of this study, it can be concluded that instructors make use of technological tools in carrying out tasks for students learning to speak in English. Technology tools such as video conferencing, email correspondence and social media conversation were found to have been used in general. These technological tools where tasks are channelled build rapport, increase fluency and accuracy, ease anxiety and apprehension and build confidence amongst students who learn to speak in English. These tools help students become skillful and competent in speaking.

\section{Ethics Committee Approval}

The author confirms that ethical approval was not required for this study. (Date of Confirmation: November 22, 2019)

\section{Acknowledgments}

I express my gratitude to Dr. Riceli C. Mendoza, my professor at all levels of my education. Thank you Ma'am for always inspiring me and pushing me to the core of my excellence. I am forever grateful.

\section{References}

Aliakbari, M., \& Jamalvandi, B. (2010). The Impact of" Role Play" on Fostering EFL Learners' Speaking Ability: A Task-Based Approach. Journal of Pan-Pacific Association of Applied Linguistics, 14(1), 15-29.

Akkara, S., Anumula, V., \& Mallampalli, M. (2020). Impact of WhatsApp Interaction on Improving L2 Speaking Skills. International Journal of Emerging Technologies in Learning (iJET), 15(3), 250-259.

Ampa, A. T., Rasyid, M. A., \& Rahman, M. A. (2013). The Implementation of Multimedia Learning Materials in Teaching English Speaking Skills. International Journal of English Language Education, 1(3), 293-304.

Bahadorfar, M., \& Omidvar, R. (2014). Technology in teaching speaking skill. Acme International Journal of Multidisciplinary Research, 2(4), 9-13. 
Fata, I. A., \& Wahyuni, S. (2016, November). Cartoon media in promoting students speaking skill in Aceh. In Proceedings of English Education International Conference, 1(2), 169-172.

Goh, C. C. (2016). Teaching speaking. In English Language Teaching Today (pp. 143-159). Springer, Cham.

Hamad, M. M., Metwally, A. A., \& Alfaruque, S. Y. (2019). The Impact of Using YouTubes and Audio Tracks Imitation YATI on Improving Speaking Skills of EFL Learners. English Language Teaching, 12(6), 191-198.

Hong, B. T. M. (2006). Teaching speaking skills at a Vietnamese university and recommendations for using CMC. Asian EFL Journal, 14(2).

Huang, H. T. D., \& Hung, S. T. A. (2010). Effects of electronic portfolios on EFL oral performance. Asian EFL Journal, 12(2), 192-212.

Idayani, A., \& Sailun, B. (2017). Roles of Integrating Information Communication Technology (ICT) in Teaching Speaking at the First Semester of English Students oF FKIP UIR. J-SHMIC: Journal of English for Academic, 4(2), 12-23.

Kayi, Н. (2012). Teaching speaking: Activities to promote speaking in a second language. Новейшие научные достижения, 12(2012).

Koşar, G. (2019). Does being taught by native English-speaking teachers promote improvement in speaking skill more? Journal of Language and Linguistic Studies, 15(3), 989-999. Doi: $10.17263 /$ jlls. 631542

Linsenmayer, M. (2011). The types and scope of phenomenology. [Online] Available: http://www.partiallyexaminedlife.com/2011/01/21/the-types-and-scope-of-phenomenology/ [January 26, 2015]

Machmud, K., \& Abdulah, R. (2017). Using smartphone-integrated model of teaching to overcome students' speaking anxiety in learning English as a foreign language. Journal of Arts and Humanities, 6(9), 01-11.

McDougald, J. S. (2009). The use of information and communication technology (ICT) in the EFL classroom as a tool to promote L2 (English) among non-native pre-service English teachers. Unpublished Thesis). Leon: The University of Leon Press.

Margret, B. (2010, July). Teaching speaking skills in English language to engineering students using language lab technology. In 2010 International Conference on Technology for Education (pp. 224225). IEEE.

Marzuki, M. J., \& Nurpahmi, S. (2019). Using video blog in teaching speaking. English Language Teaching for EFL Learners, 1(1), 13-23.

Masruddin, M. (2018). The efficacy of using short video through group work in teaching speaking to Indonesian English as Foreign Language (EFL) students. Arab World English Journal (AWEJ), 9.

Masten, L. (2008). The basics of philosophy. [Online] Available: http://www.philosophybasics.com/branch_phenomenology.html [January 28, 2015]

Miles, M. B., \& Huberman, A. M. (1994). Qualitative data analysis: A sourcebook. Beverly Hills: Sage Publications.

Morrow, R., Rodriguez, A., \& King, N. (2015). Colaizzi's descriptive phenomenological method. The psychologist, 28(8), 643-644. 
Murad, T. M., \& Smadi, O. (2009). The effect of task-based language teaching on developing speaking skills among the Palestinian secondary EFL students in Israel and their attitudes towards English. The Asian EFL Journal.

Noom-ura, S. (2008). Teaching listening speaking skills to Thai students with low English proficiency. Asian EFL Journal, 10(4), 173-192.

Parveen, B. W. (2016). Use of technology in improving speaking skills. Journal of English language and literature (JOELL), 3(2).

Qing, X. U. (2011). Role play-an effective approach to developing overall communicative competence. Cross-Cultural Communication, 7(4), 36-39.

Rakhmanina, L., \& Kusumaningrum, D. (2017). The effectiveness of video blogging in teaching speaking viewed from students' learning motivation. Proceedings of ISELT FBS Universitas Negeri Padang, 5, 27-34.

Rodrigues, P. D., \& Vethamani, M. E. (2015). The impact of online learning in the development of speaking skills. Journal of Interdisciplinary Research in Education (JIRE), 5(1).

Romaña Correa, Y. (2015). Skype ${ }^{\mathrm{TM}}$ conference calls: A way to promote speaking skills in the teaching and learning of English. Profile Issues in Teachers Professional Development, 17(1), 143156.

Rossman, R. B., \& Ralllis, S. F. (1998). Learning in the field: An introduction to qualitative research. Thousand Oaks, CA: Sage.

Smith, B. (1997). Realistic Phenomenology. [Online] Available: https://scholar.google.com.ph/scholar?hl=en\&q=daubert+realistic+phenomenology\&btnG= on [January 15, 2015]

Somdee, M., \& Suppasetseree, S. (2013). Developing English speaking skills of Thai undergraduate students by digital storytelling through websites. Proceeding of Foreign Language Learning and Teaching.

Sun, Z., Lin, C. H., You, J., Shen, H. J., Qi, S., \& Luo, L. (2017). Improving the English-speaking skills of young learners through mobile social networking. Computer assisted language learning, 30(3-4), 304-324.

Thao, V. T. (2003). The contribution of multimedia tools to EFL settings unfamiliar with technology. Asian EFL Journal, 5(3), 1-14.

Yüzlü, M. Y., \& Derin, A. T. A. Y. (2020). The effectiveness of L1 use in promoting oral production in L2 across different proficiency levels. Dil ve Dilbilimi Çalışmaları Dergisi, 16(2), 864-882.

\section{AUTHOR BIODATA}

Dr. Rowena Vasquez-Sosas is an Associate Professor and a lecturer of research and linguistics at the University of Southern Mindanao, Kidapawan City Campus, Philippines. She is inclined in qualitative methods of research in applied linguistics and language education. Most importantly, she is a proud member of the Iglesia Ni Cristo (Church of Christ) and is holding a duty in finance. 